\title{
PENERAPAN MODEL PEMBELAJARAN TWO STAY TWO STRAY (TSTS) DALAM PEMBELAJARAN PENDIDIKAN AGAMA HINDU PADA SISWA KELAS VII DI SMP NEGERI 2 MENDOYO
}

\author{
Oleh: \\ I Gusti Ayu Nilawati \\ lembaga_giga@yahoo.co.id \\ UNHI Denpasar \\ I.B Purwa Sidemen \\ purwasidemen69@gmail.com \\ UNHI Denpasar
}

\begin{abstract}
ABSTRAK
Berlakunya KBK yang dikembangkan menjadi KTSP menuntut perubahan paradigma dalam pendidikan yaitu orientasi pembelajaran yang semula berpusat pada guru beralih berpusat pada murid. Model Pembelajaran Two Stay Two Stray menjadi salah satu inovasi yang diterapkan guru pendidikan agama Hindu dalam pembelajaran pendidikan agama Hindu pada siswa kelas VII di SMP Negeri 2 Mendoyo, Jembrana. Teori konstruktivistik dan behavioristik menjadi relevan disandingkan dalam memahami berbagai fenomena yang hadir dalam penerapan model pembelajaran dimaksud. Berdasarkan analisis diperoleh hasil penelitian sebagai berikut: (1) pembelajaran pendidikan agama Hindu dilakukan dengan cara pembagian kelompok secara heterogen dan melaksanakan setiap tahapan-tahapan dari model pembelajaran Two Stay Two Stray, (2) guru dapat melatih siswa menjadi lebih aktif lagi dalam menerima proses pembelajaran pendidikan agama Hindu, (3) kendala-kendala yang dihadapi guru agama Hindu dalam penerapan model pembelajaran Two Stay Two Stray yaitu ada beberapa siswa yang kurang mengerti dengan tujuan bertamu ke kelompok lain dan siswa yang aktif di dalam model pembelajaran ini hanya beberapa saja, sehingga pembelajaran kurang efektif karena waktu yang diperlukan juga cukup panjang. Dengan demikian guru harus benar-benar menjelaskan kepada siswa tujuan dari bertamu dan mengatur waktu agar tidak kekurangan waktu.
\end{abstract}

Kata kunci: penerapan, model pembelajaran Two Stay Two Stray, pendidikan agama Hindu.

\section{ABSTRACT}

The validity of the KBK developed into KTSP requires a paradigm shift in education, namely the orientation of learning initially centered on the teacher turned student-centered. The Two Stay Two Stray Learning Model has become one of the innovations applied by Hindu religious education teachers in teaching Hindu religious education to VII grade students of Mendoyo Public Middle School 2, Jembrana. The constructivist and behavioristic theories become relevant juxtaposed in understanding various phenomena present in the application of the intended learning model. Based on the analysis, the results of the study are as follows: (1) Hindu religious education learning is carried out by dividing heterogeneous groups and 
implementing each of the stages of the Two Stay Two Stray learning model, (2) teachers can train students to be more active in accepting the process Hindu religious education learning, (3) the constraints faced by Hindu teachers in applying the Two Stay Two Stray learning model, namely there are some students who do not understand with the aim of visiting other groups and students who are active in this learning model are only a few, so learning is less effective because the time required is also quite long. Thus the teacher must really explain to the students the purpose of visiting and arrange for time so as not to lack time.

Key words: implementation, Two Stay Two Stray learning model, Hindu religion education.

\section{PENDAHULUAN}

Pendidikan merupakan salah satu kebutuhan pokok manusia. Menurut Undang-undang Republik Indonesia No. 20 Tahun 2003 tentang Sistem Pendidikan Nasional menyebutkan bahwa Pendidikan Nasional berfungsi untuk mengembangkan kemampuan dan membentuk watak serta peradaban bangsa yang bermartabat dalam rangka mencerdaskan kehidupan bangsa. Pendidikan bertujuan untuk mengembangkan potensi peserta didik agar menjadi manusia yang beriman dan bertakwa kepada Tuhan Yang Maha Esa, berahlak mulia, berilmu, sehat, cakap, kreatif, mandiri, dan menjadi warga negara yang baik serta bertanggung jawab. Sejak bangsa Indonesia memperoleh kemerdekaan pada tahun 1945, sistem pendidikan nasional sudah mulai dibangun untuk mendidik putra putri bangsa Indonesia dalam rangka mendukung terwujudnya tujuan nasional (Rohman, 2009). Dalam hal ini ada beberapa faktor yang berpengaruh terhadap sistem pendidikan yaitu faktor guru, faktor siswa, sarana, alat dan media untuk mencapai keberhasilan dalam hidup pendidikan, maka keterpaduan antara kegiatan guru dengan siswa serta peran masyarakat sangat diperlukan (Liani, 2014: 2).

Dalam upaya meningkatkan hasil pembelajaran tentunya tidak terlepas dari upaya peningkatan kualitas pembelajaran di sekolah. Berlakunya Kurikulum Berbasis Kompetensi (KBK) yang di kembangkan menjadi Kurikulum Tingkat Satuan Pedidikan (KTSP) yang kemudian dikembangkan lagi menjadi Kurikulum 2013 menurut perubahan paradigma dalam pendidikan dan pembelajaran, khususnya pada jenis dan jenjang pendidikan formal. Perubahan tersebut harus diikuti oleh guru yang bertanggung jawab atas penyelenggaraan pembelajaran dikelas (Winartutik, 2014:3). Satu inovasi yang menarik mengiringi perubahan paradigma tersebut adalah ditemukan dan di terapkannya model pembelajaran Two Stay Two Stray pada proses pembelajaran di SMP Negeri 2 Mendoyo. Salah satunya pada proses pembelajaran pendidikan agama Hindu. Model pembelajaran Two Stay Two Stray (TSTS) dapat di jadikan sebagai suatu strategi pembelajaran untuk membuat siswa aktif dalam belajar.

Dalam proses pembelajaran Agama Hindu di sekolah menengah pertama (SMP), guru merupakan faktor yang sangat penting dalam menentukan kualitas pembelajaran. Agar dapat meningkatkan kualitas pembelajaran di dalam kelas, maka diperlukan untuk menerapkan model pembelajaran kooperatif. Menurut Anita Lie (2004), bahwa model pembelajaran kooperatif merupakan suatu sistem pengajaran yang memberi kesempatan kepada peserta didik untuk bekerja sama dengan peserta didik lainnya dalam menyelesaikan tugas-tugas yang terstruktur. Dan didalam pembelajaran kooperatif siswa 
belajar bersama dalam kelompok-kelompok kecil saling membantu satu sama lain. Di dalam satu kelompok yang terdiri dari 4 atau 5 siswa, dengan kemampuan yang heterogen atau bervariasi.

Dalam penggunaan strategi pembelajaran yang meliputi tentang model dan teknik, yang sesuai dengan karakteristik mata pelajaran khususnya Agama Hindu sangat diperlukan agar membantu siswa untuk meningkatkan kreatifitas dalam pembelajaran pendidikan Agama Hindu. Salah satu model pembelajaran yang akan diterapkan adalah model pembelajaran Two Stay Two Stray (TSTS). Model pembelajaran TSTS merupakan model pembelajaran kooperatif yang berarti " dua tinggal dua tamu" yang dikembangkan oleh Spencer Kagan (1992). Model pembelajaran TSTS ini hampir mirip dengan model pembelajaran kepala bernomor ( Numbered Heads). Pembelajaran Two Stay Two Stray (TSTS) merupakan pembelajaran yang memberikan kesempatan kepada kelompok untuk membagikan hasil dan informasi kepada kelompok lain sesuai dengan hasil diskusi dikelompoknya.

Dengan menerapkan model pembelajaran Two Stay Two Stray ini akan mengarahkan siswa untuk aktif, baik dalam berdiskusi, tanya jawab, mencari jawaban, menjelaskan dan juga menyimak materi yang dijelaskan oleh temannya. Alur strategi TSTS dimulai dari persiapan yang dilakukan oleh guru dalam membuat silabus, serta sistem penilaian, desain pembelajaran, mempersiapkan tugas siswa, dan membagi siswa menjadi beberapa kelompok dengan masing-masing anggota 4 siswa. Pada saat mempersiapkan kelompok belajar, hal yang harus diperhatikan adalah membentuk kelompok-kelompok belajar yang heterogen ditinjau dari segi jenis kelamin dan kemampuan akademis. Dan berdasarkan sisi jenis kelamin, dalam satu kelompok harus ada siswa laki-laki dan perempuannya.
Sedangkan berdasarkan kemampuan akademis maka dalam satu kelompok terdiri dari satu orang yang berkemampuan akademis tinggi, dua orang dengan kemampuan sedang, dan satu orang lagi yang berkemampuan rendah atau kurang.

Selanjutnya guru menyampaikan indikator pembelajaran yang harus dicapai oleh siswa, memperkenalkan dan menjelaskan materi sesuai dengan rencana pembelajaran yang telah disusun didalam silabus dan RPP. Untuk mengatasi permasalahan, guru menetapkan alternatif pemecahan masalah dengan menerapkan model inovatif, dimana guru berperan sebagai fasilitator, motivator, evaluator, dan transformator. Siswa belajar konstruktivis, membangun sendiri pengetahuan yang diperoleh, menemukan bersama kelompok, adanya interaksi pembelajaran dan lingkungan sebagai sumber belajar. Salah satu model pembelajaran yang dipilih adalah Two Stay Two Stray. Model ini dapat digunakan untuk memberikan konsep materi sulit kepada siswa serta dapat digunakan untuk mengetahui sejauh mana pengetahuan dan kemampuan siswa pada materi tersebut. Pada model pembelajaran Two Stay Two Stray ini memberikan kesempatan bagi siswa untuk berpikir lebih banyak menjawab soal dan membantu satu sama lain dalam kelompok belajar sehingga proses pembelajaran berlangsung lebih bermakna dan menarik bagi siswa.

\section{PEMBAHASAN}

\subsection{Implementasi Model}

Pembelajaran Two Stay Two Stray dalam

Pembelajaran Pendidikan Agama Hindu Pada Siswa Kelas VII di SMP Negeri 2 Mendoyo

Dalam proses pembelajaran guru harus mempunyai kompetensi yang dapat membuat pembelajaran itu menjadi efektif, salah satu tugas seorang guru adalah guru sebagai fasilitator, dimana guru bertugas 
memfasilitasi murid untuk menemukan dan mengembangkan bakatnya secara pesat. Guru harus dapat mengajak, merangsang, dan memberikan stimulus kepada siswa agar mampu mengoptimalkan kecerdasannya dan kecakapannya secara bebas, tetapi tetap bertanggung jawab. Dalam upaya meningkatkan pembelajaran, banyak upaya yang telah diterapkan misalnya dengan menggunakan model pembelajaran. Salah satu model pembelajaran yang dapat di terapkan oleh guru adalah model pembelajaran Two Stay Two Stray.

Two Stay Two Stray adalah salah satu model pembelajaran yang menarik untuk diberikan kepada siswa. Model ini menyenangkan, menantang, dan mewajibkan peserta untuk saling bertukar informasi dengan kelompok lain. Dalam kegiatan pembelajaran dengan menggunakan model two stay two stray ini tidak hanya menuntut siswa untuk aktif dalam menyelesaikan tugas yang diberikan oleh guru. Akan tetapi mereka juga melakukan aktivitas fisik yaitu pada saat mereka bertamu ke kelompok lain, untuk saling bertukar informasi dari hasil diskusinya dengan kelompok lain. Dengan demikian, tiap dua anggota dari setiap kelompok akan mempersiapkan diri untuk bertamu ke kelompok lain. Two Stay artinya dua anggota yang masih tinggal didalam kelompoknya, yang bertugas untuk membagikan hasil diskusinya dengan kelompok lain. Sedangkan Two Stray artinya dua anggota yang akan bertamu ke kelompok lain, yang bertugas untuk mencatat dan menyimak hasil dikusi dari kelompok lain. Jadi dalam model pembelajaran Two Stay Two Stray ini dapat melatih siswa untuk saling berinteraksi dengan kelompok lain, saling bertukar informasi dan dapat membuat siswa lebih aktif dalam belajar. Two Stay Two Stray ini merupakan pembelajaran yang dapat digunakan untuk memberikan konsep pemahaman materi sulit kepada siswa serta dapat digunakan untuk mengetahui sejauh mana pengetahuan dan kemampuan siswa dalam menguasai materi.

Sebelum guru menerapkan model pembelajaran Two Stay Two Stray ini, yang harus dilakukan oleh guru adalah menyusun RPP, mempersiapkan sub pokoknya, merancang pembagian peserta didik menjadi beberapa kelompok secara heterogen. Setelah itu baru guru melaksanakan setiap tahapan-tahapan yang ada di dalam model pembelajaran Two Stay Two Stray.

Dengan menggunakan model pembelajaran ini siswa dapat bertukar pikiran dengan temannya dan siswa juga di berikan kesempatan untuk membagi hasil diskusinya kepada kelompok lain, sehingga lebih mudah untuk menyelesaikan suatu masalah atau soal yang diberikan. Model Pembelajaran Two Stay Two Stray dapat dijadikan sebagai suatu solusi dan strategi dalam proses pembelajaran pendidikan agama Hindu pada siswa semua kelas khususnya kelas VII. Dengan penerapan model pembelajaran Two Stay Two Stray diharapkan dapat menjawab tantangan dalam melaksanakan proses pembelajaran pada siswa beragam dan tujuan pendidikan yang telah dirumuskan dapat tercapai dengan baik.

Dalam proses pembelajaran tidak dapat terlepas dari tujuan pendidikan yang hendak dicapai. Dalam kegiatan pendidikan, tujuan memiliki kedudukan yang amat penting, lebih-lebih bila dibandingkan di antara aneka komponen lain dalam penyelenggaraan pendidikan, tujuan pendidikan merupakan komponen yang amat fital. Sehingga dapat dikatakan bahwa semua komponen diadakan, seluruh kegiatan pendidikan diupayakan, semuanya sematamata hanyalah tertuju kepada pencapaian tujuan pendidikan.

Kurikulum merupakan seperangkat rencana dan pengaturan mengenai tujuan, isi 
dan bahan pelajaran serta cara yang digunakan sebagai pedoman penyelenggaraan kegiatan pembelajaraan untuk mencapai tujuan pendidikan tertentu. Dalam profil SMP Negeri 2 Mendoyo, menyatakan bahwa tujuan umum SMP Negeri 2 Mendoyo berdasarkan Pancasila dan Undang-Undang Dasar 1945, adalah mengembangkan kemampuan dan membentuk watak serta peradaban bangsa, bertujuan untuk mengembangkan potensi siswa agar menjadi manusia yang beriman dan bertaqwa kepada Tuhan Yang Maha Esa, berakhlak mulia, sehat, berilmu, cakap, kreatif, mandiri, dan menjadi warga negara yang cerdas, demokratis serta bertanggung jawab.

Kuriklum yang digunakan untuk mencapai tujuan umum pendidikan yang telah ditetapkan di SMP Negeri 2 Mendoyo dalam proses pembelajaran pendidikan agama Hindu adalah Kurikulum Tingkat Satuan Pendidikan (KTSP), hal ini dipertegas dengan temuan bahwa untuk pendidikan agama Hindu sampai saat ini masih menggunakan kurikulum KTSP, karena belum ada diklat penerapan kurikulum 2013 untuk pendidikan agama Hindu, sejauh ini penerapan kurikulum untuk siswa semua kelas yaitu dengan cara rolling. Penerapan kurikulum dimulai dari kurikulum kelas VIIA, dilanjutkan kelas VIIB sampai dengan kelas VIIH sehingga setiap anak tetap mendapatkan pendidikan agama Hindu secara utuh sesuai tuntutan kurikulum, hanya saja dengan cara penerapan yang berbeda pada umumnya.

Dalam penuturan di atas dapat disimpulkan, bahwa penerapan model pembelajaran Two Stay Two Stray ini dapat diterapkan dengan menggunakan kurikulum KTSP. Dalam proses pembelajaran tentunya ditunjang dengan kurikulum, saat ini SMP Negeri 2 Mendoyo masih menggunakan kurikulum KTSP karena belum ada diklat kurikulum 2013 sehingga setiap anak tetap mendapatkan pendidikan agama Hindu hanya saja dengan cara penerapan yang berbeda pada umunya.

Sebagaimana yang sering dikemukakan, perkembangan terhadap proses belajar mengajar membawa konsekuensi kepada guru untuk meningkatkan kompetensinya, karena dalam proses belajar mengajar dan hasil belajar siswa sebagian besar ditentukan oleh peran serta kompetensi guru. Guru yang kompeten akan lebih mampu menciptakan lingkungan belajar yang efektif dan akan lebih mampu mengelola kelasnya, sehingga hasil belajar siswa berada pada tingkat yang optimal. Selain itu peranan kepala sekolah sangat mendukung proses pembelajaran.

\subsection{Guru Menerapkan Model Pembelajaran Two Stay Two Stray dalam Pembelajaran Pendidikan Agama Hindu Pada Siswa Kelas VII}

Dalam proses pembelajaran, guru agama Hindu memiliki peran penting dalam menuntun siswa siswinya untuk menuju kesuksesan. Pembelajaran merupakan proses membelajarkan siswa dari tidak tahu menjadi tahu, dari tidak bisa menjadi bisa. Di sinilah peran guru agama Hindu sangat diharapkan mampu mendidik siswa agar mengalami perubahan yang positif dalam proses pembelajaran. Untuk mencapai hasil belajar yang optimal, dianjurkan agar guru membiasakan diri menggunakan komunikasi banyak arah atau komunikasi sebagai transaksi, yakni komunikasi yang tidak hanya melibatkan interaksi dinamis antara peserta didik yang satu dengan peserta didik yang lainnya.

Penerapan model pembelajaran Two Stay Two Stray dalam pembelajaran pendidikan agama Hindu ini sudah pernah di terapkan oleh guru pendidikan agama Hindu itu sendiri. Namun dalam menerapankan model pembelajaran ini tidak dilakukan 
secara berlanjut, hanya dilakukan pada beberapa kali pertemuan saja. Dalam menerapkan model pembelajaran ini yang dilakukan oleh guru pendidikan agama Hindu adalah melaksanakan setiap tahaptahap yang ada di dalam model pembelajaran two stay two stray. Hal ini sesuai dengan apa yang dikatakan oleh guru agama Hindu SMP Negeri 2 Mendoyo. Penerapan model pembelajaran Two Stay Two Stray pada pembelajaran pendidikan agama Hindu ini sudah pernah saya terapkan di kelas VII tetapi tidak dilakukan secara berlanjut, hanya di lakukan pada beberapa kali pertemuan saja dan saya menggunakan model pembelajaran ini dengan cara membentuk sistem kelompok secara heterogen yang mana setiap kelompok yang dibagi menjadi delapan kelompok terdiri dari empat anggota.

Setelah berdiskusi dengan kelompok lain, guru mengarahkan siswa untuk kembali ke bentuk formal atau kembali pada kelompok masing-masing untuk mencocokan kembali mengenai hasil diskusi yang sudah didapatkan dari kelompok lain. Selanjutnya guru meminta salah satu anggota peserta didik dari masing-masing kelompok presentasi dan menyampaikan hasil diskusinya di depan kelas.

Penggunaan model pembelajaran Two Stay Two Stray dalam pembelajaran pendidikan agama Hindu pada siswa kelas VII di SMP Negeri 2 Mendoyo ternyata dapat membuat peserta didik menjadi lebih aktif dalam belajar. Hasilnya dapat dilihat dari sebelum dan sesudah menerapkan model pembelajaran Two Stay Two Stray. Sebelum menerapkan model pembelajaran Two Stay Two Stray, peserta didik cenderung tidak fokus dalam menyelesaikan tugas kelompoknya masing-masing dan kurang bertanggung jawab terhadap kelompoknya. Karena kurangnya tantangan dalam menyelesaikan tugas kelompok. Namun setelah menerapkan model pembelajaran Two Stay Two Stray, peserta didik menjadi lebih aktif dalam menyelesaikan tugas kelompoknya. Karena peserta didik dari masing-masing kelompok memiliki tugasnya masing-masing, misalnya ada yang bertugas menetap didalam kelompoknya dan ada juga yang bertugas untuk bertamu ke kelompok lain. Sehingga dengan menerapkan model pembelajaran Two Stay Two Stray ini menuntut peserta didik untuk lebih aktif lagi dalam menyelesaikan tugas kelompoknya dan bertanggung jawab atas kelompoknya. Sesuai dengan penuturan diatas dapat disimpulkan, bahwa dengan menerapkan model pembelajaran Two Stay Two Stray ini dapat membuat peserta didik menjadi lebih aktif dan bisa lebih fokus dalam menerima pembelajaran khususnya pelajaran pendidikan agama Hindu.

\subsection{Kendala-kendala Yang Dihadapi Guru dan Solusinya dalam Penerapan Model Pembelajaran Two Stay Two Stray Pada Pembelajaran Pendidikan Agama Hindu Siswa Kelas VII di SMP Negeri 2 Mendoyo}

Setiap pengajar tentunya menginginkan pengajarannya dapat diterima dengan sejelas-jelasnya oleh peserta didik untuk menciptakan sumber daya manusia yang berkualitas. Untuk dapat memberikan pengajaran yang baik tentunya guru menggunakan model-model pembelajaran sebagai salah satu cara penyampaian informasi agar dapat diterima dengan mudah dan dapat dipahami. Sebelum menggunakan model pembelajaran guru harus menyesuaikan terlebih dahulu apakah metode yang akan digunakan cocok diterapkan pada materi pengajaran yang akan diberikan. Adapun faktor-faktor yang menyebabkan kesulitan dalam proses model pembelajaran Two Stay Two Stray pada siswa kelas VII di SMP Negeri 2 Mendoyo adalah sebagai berikut. 


\subsubsection{Faktor Internal dan Eksternal Yang Dikaji dari Guru \\ Killen (1998) dalam Aunurahman} (2013), menyatakan strategi pembelajaran, metode teknik-teknik evaluasi yang akan dipergunakan, maka guru terlebih dahulu dituntut untuk memahami karateristik siswa dengan baik. Meskipun guru secara sungguh-sungguh telah berupaya merancang dan melaksanakan kegiatan pembelajaran dengan baik, namun masalah-masalah belajar tetap akan dijumpai guru. Hal ini merupakan pertanda bahwa belajar merupakan kegiatan yang dinamis sehingga guru perlu secara terus menerus mencermati perubahan-perubahan yang terjadi pada siswa dikelas. Guru agama Hindu di SMP Negeri 2 Mendoyo juga mengalami masalah belajar meskipun telah berusaha memaksimalkan proses pembelajaran dengan baik. Berikut masalah-masalah baik internal dan eksternal dikaji dari dimensi guru dalam penerapan model pembelajaran Two Stay Two Stray dalam pembelajaran pendidikan agama Hindu pada siswa kelas VII di SMP Negeri 2 Mendoyo diantaranya yaitu:

1. Sarana

2. Kurikulum Sekolah

3. Dukungan dari Pihak Sekolah

Kendala yang dihadapi dalam penerapan model pembelajaran Two Stay Two Stray ini adalah tidak banyaknya dukungan dari pihak sekolah seperti Kepala Sekolah, Guru dan Pegawai. Dalam hal ini juga kurangnya sarana dan prasarana di dalam menerapkan model pembelajaran Two Stay Two Stray ini seperti kurangnya buku paduan untuk membantu peserta didik mendapatkan materi pelajaran yang lengkap selain buku LKS.

Dalam hal ini di dalam menerapkan model pembelajaran Two Stay Two Stray harus adanya dorongan dari pihak sekolah diantaranya Kepala Sekolah, Guru, dan juga Pegawai yang ada di lingkungan sekolah. Adanya sarana prasarana juga harus mendukung sehingga pembelajaran berjalan dengan lancar.

\subsubsection{Faktor Internal dan Eksternal yang dikaji dari Siswa}

Faktor Internal diartikan sebagai faktor penyebab kesulitan belajar peserta didik yang bersumber dari dalam dirinya. Keberhasilan siswa di samping ditentukan oleh faktor-faktor internal juga turut dipengaruhi oleh faktor-faktor eksternal. Faktor eksternal adalah segala faktor yang ada di luar diri siswa yang memberikan pengaruh terhadap aktivitas dan hasil belajar yang dicapai siswa. Faktor internal dan eksternal yang dimaksud dalam penelitian ini diartikan sebagai faktor yang menghambat penerapan model pembelajaran Two Stay Two Stray dalam pembelajaran pendidikan agama Hindu di SMP Negeri 2 Mendoyo, baik yang bersumber dari dalam diri siswa maupun yang bersumber dari luar diri siswa. Kendala tersebut yakni: Konsentrasi Belajar, Motivasi Belajar, Lingkungan Sosial

\subsection{Solusi Yang Dilakukan Untuk Mengatasi Kendala-Kendala Yang Dihadapi dalam Penerapan Model Pembelajaran Two Stay Two Stray dalam Pembelajaran Pendidikan Agama Hindu Pada Siswa Kelas VII di SMP Negeri 2 Mendoyo}

Dalam suatu proses pembelajaran khususnya dalam pendidikan agama Hindu di SMP Negeri 2 Mendoyo, kecamatan mendoyo, kabupaten jembrana. Berdasarkan kendala-kendala yang dihadapi guru agama Hindu maka perlu adanya solusi dalam mengatasi kendala yang terjadi guna tercapainya tujuan suatu proses pembelajaran. Adapun solusi yang harus 
dilakukan guru agama Hindu untuk mengatasi kendala-kendala yang dihadapi dalam penerapan model pembelajaran two stay two stray dalam pembelajaran agama Hindu pada siswa kelas VII di SMP Negeri 2 Mendoyo adalah motivasi, arahan, dan pembelajaran yang menyenangkan.

\subsubsection{Memberikan Motivasi Kepada Siswa}

Sebagai seorang siswa rasa lelah, jenuh dan beberapa alasan lain bisa muncul setiap saat. Disinilah unsur guru sangat penting dalam memberikan motivasi, mendorong dan memberikan respon positif guna membangkitkan kembali semangat siswa yang mulai menurun. Guru seolah sebagai alat pembangkit motivasi bagi peserta didiknya. Adapun hal-hal yang dapat dilakukan guru agama Hindu dalam memotivasi siswa pada saat proses pembelajaran yaitu: memberikan pujian dan memberikan point atau nilai.

\subsubsection{Memberikan Arahan Kepada Siswa Yang Tidak Memperhatikan Guru Saat Mengajar}

Pada saat proses pembelajaran berlangsung ada siswa yang bermain-main atau mengganggu teman yang sedang belajar, hal itu dapat dicegah atau diatasi dengan mengatur siswa tersebut, memanggil namanya dan memberikan dia pertanyaan dengan begitu siswa itu tidak akan lagi berani mengganggu temannya dan bermainbermain dan dia akan lebih memperhatikan gurunya saat belajar.

\subsubsection{Memberikan Pembelajaran Yang Menyenangkan}

Pembelajaran yang menyenangkan merupakan pembelajaran yang mampu meningkatkan semangat belajar siswa dan mampu mengurangi rasa bosan pada saat belajar, pembelajaran yang menyenangkan juga mampu mengurangi keteganganketegangan siswa saat mengikuti pelajaran.

Para guru hendaknya menyadari bahwa pembelajaran yang menyenangkan dapat meningkatkan keberhasilan dalam proses pembelajaran. Oleh karena itu, guru hendaknya dapat menciptakan suasana yang menyenangkan dalam setiap proses pembelajaran. Dengan menggunakan model pembelajaran ini dapat memberikan suatu proses pembelajaran yang menyenangkan pada siswa. Sehingga siswa tidak cepat bosan pada saat menerima pembelajaran yang diberikan oleh gurunya.

\section{Penutup}

Berdasarkan hasil penelitian, maka dapat ditarik simpulan bahwa penerapan model pembelajaran two stay two stray dalam pembelajaran pendidikan agama Hindu pada siswa kelas VII di SMP Negeri 2 Mendoyo yaitu dengan cara pembagian kelompok secara heterogen, dan melaksanakan setiap tahapan-tahapan dari model pembelajaran Two Stay Two Stray. Dengan menggunakan model pembelajaran ini siswa dapat lebih aktif dalam menerima pembelajaran, dan juga dapat melatih siswa untuk memecahkan masalah secara musyawarah yang nantinya akan mendapatkan jawaban yang memuaskan serta dapat menjadikan siswa yang mandiri dan kritis. Hal ini dapat dilihat pada saat siswa membagi diri untuk bertamu ke kelompok lain dan saling bertukar informasi. Penggunaan model pembelajaran Two Stay Two Stray dalam pembelajaran pendidikan agama Hindu ini dapat membantu siswa untuk bisa aktif dalam belajar dan juga melatih siswa untuk bisa bersosialisasi dengan baik antara siswa. Respons siswa dalam pembelajaran pendidikan agama Hindu dengan menggunakan model pembelajaran Two Stay Two Stray sangat antusias dan bersemangat. Adapun bentuk motivasi yang digunakan oleh guru 
pendidikan agama Hindu untuk mempertahankan minat peserta didik terhadap bahan pelajaran yang diberikan adalah dengan cara memberi poin dan pujian. Guru menerapkan model pembelajaran two stay two stray di SMP Negeri 2 Mendoyo karena dengan menggunakan model pembelajaran ini guru dapat melatih siswa untuk lebih aktif lagi dalam menerima pembelajaran pendidikan agama Hindu dan dapat juga melatih siswa lebih tanggap dalam menyampaikan dan menyimak hasil diskusi dengan kelompok lain, sehingga dalam proses pembelajaran pendidikan agama Hindu tidak membonsankan bagi siswa. Dengan adanya model pembelajaran Two Stay Two Stray ini proses pembelajaran menjadi menyenangkan dan siswa juga dituntut untuk aktif dalam belajar karena siswa dapat bertukar informasi kepada kelompok lain. Dengan menggunakan model pembelajaran Two Stay Two Stray guru dapat melihat sejauh mana pengetahuan dan kemampuan siswa dalam menguasai materi pembelajaran pendidikan agama Hindu.

Kendala-kendala yang dihadapi guru agama Hindu dalam penerapan model pembelajaran Two Stay Two Stray pada siswa kelas VII di SMP Negeri 2 Mendoyo yaitu: adanya siswa yang malas serta kurang semangat belajar saat berdiskusi dengan kelompoknya, ada juga beberapa siswa yang kurang mengerti dengan tujuan bertamu ke kelompok lain, siswa yang aktif di dalam model pembelajaran ini hanya beberapa saja sehingga pembelajaran kurang efektif. Model pembelajaran Two Stay Two Stray ini memerlukan waktu yang sangat panjang. Padahal waktu pembelajaran di dalam kelas sangat terbatas sehingga keterbatasan itu tidak mungkin dapat menghasilkan sesuatu secara tuntas. Namun hal ini tidak perlu dirisaukan oleh guru. Sebab dengan perencanaan dan persiapan yang matang kejadian semacam itu bisa dihindari. Selain adanya kendala-kendala pada saat menerapkan model pembelajaran Two Stay Two Stray, adapun solusi untuk mengatasi kendala-kendala tersebut yaitu: guru harus benar-benar menerangkan kepada siswa mengenai maksud dan tujuan dari bertamu, guru juga harus memberikan motivasi kepada siswa yaitu dengan pemberian nilai atau point, dan dapat menciptakan lingkungan belajar yang efektif dan kondusif.

\section{DAFTAR PUSTAKA}

Koentjaraningrat. 1997. Metode-Metode Penelitian Masyarakat. Jakarta: Gramedia

Liani, Ni Putu. 2014. "Penerapan Model Snowball Throwing Dalam Pembelajaran Pendidikan Agama Hindu Di SD No. 4 Dajan Peken, Kecamatan Tabanan, Kabupaten Tabanan”. Skripsi (tidak diterbitkan) Program Studi Pendidikan Agama Hindu, Fakultas Pendidikan Agama dan Seni, Universitas Hindu Indonesia. Denpasar.

Lie, Anita. 2004. Cooperatif Learning: Mempraktekkan Cooperatif Learning di Ruang-Ruang Kelas. Jakarta: PT. Grasindo.

Nurdin, Muhamad. 2004. Kiat Menjadi Guru Profesional. Jogyakarta : Prisma Sophie. 
Penyanyat, Harid 2013. "Pembahasan Metode Two Stay Two Stray". academia.edu. (akses tanggal 14 Oktober 2014). Tersedia dalam URL: www.academia.edu/8266320/PEMBAHASAN_METODE_TWO_STAY_TWO_STRAY

PHDI. 1997/1998. Himpunan Keputusan Kesatuan Terhadap Aspek Agama Hindu I-XV. Proyek Peningkatan Pasraman dan Sarana Kehidupan Bangsa: Denpasar.

Rohman, Arif. 2009. Memahami Pendidikan \& Ilmu Pendidikan. Yogyakarta: Laksbang Mediatama.

Sagala, Syaiful. 2003. Konsep dan Makna Pembelajaran: Untuk Membantu Memecahkan Problematika Belajar dan Mengajar. Bandung: Alfabeta.

Sugiyono. 2008. Metodelogi Kuantitatif, Kualitatif, R\&D. Bandung: Alfabeta.

Sharan, Shlomo. 2014. Cooperatif Learning : Inovasi Pengajaran dan Pembelajaran Untuk Memacu Keberhasilan Siswa di Kelas. Yogyakarta : Istana Media.

Salfin, Robert E. 2005. “Cooperatif Lerning Teori, Risert dan Praktik”. Bandung: Nusa Media.

Sanjaya, Wina. 2010. Strategi Pembelajaran Berorientasi Standar Proses Pendidikan. Jakarta: Kencana Prenada Media Group.

Sukardi. 2003. Metode Penelitian Pendidikan. Jakarta: Bumi Aksara.

Suwardani, Ni Putu et al. 2012. Pedoman Penulisan Usulan Penelitian Skripsi. Denpasar: Pustaka Larasan.

Tim Penyusun Kamus Pusat Pembinaan dan Pengembangan Bahasa. 1989. Kamus Besar Bahasa Indonesia. Jakarta: Balai Pustaka.

Trianto, M.Pd. 2008. Mendesains Pembelajaran Kontekstual di Kelas. Jakarta: Kencana Prenada Media Group. 